\title{
Minor Salivary Glands Morphology in Xerostomia Patients
}

\author{
Morfología de las Glándulas Salivales Menores en Pacientes Xerostomizados \\ "Bianca Maria Liquidato; *Mirna Duarte Barros; * ${ }^{*}$ Ivo Bussoloti Filho; \\ "Celina Siqueira Barbosa Pereira \& *Maria Inêz Marcondes Macéa
}

LIQUIDATO, B. M.; BARROS, M. D.; BUSSOLOTI FILHO, I.; PEREIRA, C. S. B. \& MACÉA, M. I. M. Minor salivary glands morphology in xerostomia patients. Int. J. Morphol., 24(3):489-493, 2006.

SUMMARY: The minor salivary glands are found scattered throughout the oral mucosa, especially in the lips and soft palate mucosa. Several factors can cause xerostomia, whereas the salivary glands histological characteristics are also considered as factors for defining the etiology. Thus, the minor salivary glands biopsy represents an essential tool for attending the required diagnosis criterion in the classification of Sjögren's Syndrome patients, since it does not present risk for the patient. The objective of this study is to determine the histological description of the minor salivary glands obtained from the biopsies of xerostomia patients and to classify the minor salivary gland histological aspect as the Sjögren's Syndrome. Forty laminas of xerostomia patients that were submitted to minor salivary glands biopsy at the Santa Casa de Sao Paulo Stomatology ambulatory were retrospectively studied. The variation in the glands histological aspect was observed, from the normality up to the presence of inflammatory focus, replacing the conjunctive between acini and ducts, as well as the parenchyma. In 15 cases, the infiltrated inflammatory cells amounted to focus, that is to say, groups of at least 50 inflammatory cells around the acini or ducts, which is a characteristic aspect of the Sjögren's Syndrome. Therefore, the finding of at least one inflammatory focus of $4 \mathrm{~mm}^{2}$ of glandular tissue represents a set criterion, although, not the only one in order to classify this patient as having the Sjögren's Syndrome.

KEY WORDS: Sjögren's syndrome; Xerostomia; Salivary glands; Saliva; Diagnosis.

\section{INTRODUCTION}

The minor salivary glands are found scattered in the lamina propria of the entire oral mucosa, with concentrations in the lips and soft palate mucosa. They are predominantly mucous glands, which volume of produced secretion corresponds to approximately $10 \%$ of the total saliva. Saliva takes part in tasting, mastication, deglutition, and speech processes performing functions such as digestion of amide and lipids, mucosa defense through lubricating action, and enzyme antimicrobial activity, such as lysozyme, lactoferrin, and sialoperoxidase (Kierszembaum, 2004; Scully, 2001). The decrease in the volume of secretion leads to deglutition and speech impairments, adding to complications including erythematous candidiasis and caries (Daniels, 2000).

Xerostomia is the subjective sensation of dry mouth, which can be caused by several factors: metabolic diseases, such as diabetes; autoimmune diseases, such as Sjögren's Syndrome; radiotherapy of head and neck and the use of medications, such as antihistamines, antihypertensive, and antidepressants, among others (Fox, 1996).
The histological characteristics of the salivary glands are important factors that will take part, besides the clinical history and laboratorial proofs, for defining the xerostomia etiology. Nevertheless, there is a high level of morbidity when performing the major salivary glands biopsy, leading to the formation of fistulas and lesion in the branches of the facial nerve. Thus, the minor salivary glands biopsy represents an alternative for the diagnosis, since it is an essential tool for defining different criteria for the classification of Sjögren's Syndrome patients, and for not presenting a risk for the patient as well.

Despite of these factors, the use of minor salivary gland biopsy still remains controversial in the literature, specially regarding the number of focus considered sugestive of Sjögren's Syndrome, if 1 or 2 foci in $4 \mathrm{~mm}^{2}$ of glandular tissue (Daniels, 1984; Lindahl \& Hedfors, 1989; Vitali et al., 1993). The possible presence of inflammatory focus in other clinical situations, as graft versus host disease and hepatitis C (Lindahl \& Hedfors, 1989; Vitali et al., 2002) and

\footnotetext{
* Depto. de Morfologia da Faculdade de Ciências Médicas da Santa Casa de São Paulo, Brasil.

*** Depto. de Otorrinolaringologia da Faculdade de Ciências Médicas da Santa Casa de São Paulo, Brasil.

Sponsorship: CNPq-Brazil (Doctorate Postgraduate Program).
} 
the eventual influence of external factors as smoking in the histological aspect are also subject of discussion in the literature (Manthorpe et al., 2000).

The objective of this study is to determine the histological description of the minor salivary glands obtained from the biopsies of xerostomia patients and to classify the minor salivary gland histological aspect as compatible with the Sjögren's Syndrome.

\section{MATERIAL AND METHOD}

We conducted a retrospective study on 40 cases of xerostomia patients submitted to minor salivary glands biopsy, who were taken to Santa Casa de São Paulo Stomatology ambulatory, during the period of January 1997 to September 2003.

The minor salivary glands biopsy was performed through a horizontal incision in the mucosa of the vestibular side of the lower lip, parallel to the red part, dissecting 4 to 6 minor salivary glands. The material was fixed in $10 \%$ formalin, embedded in paraffin, and submitted to sections in rotating disc microtome, obtaining slices with $3 \mu \mathrm{m}$ thickness. The slices were dyedstained with hematoxylin and eosin (HE).

We observed the slices with the use of a microscope Zeiss Axioskop $40^{\mathrm{TM}}$ model, coupled to an Intel Pentium III ${ }^{\mathrm{TM}}$ processing computer, and with the Axiovision $3.1^{\mathrm{TM}}$ program assistance for the delimitation of the glandular tissue area. The glandular tissue was measured under 50X magnification, whereas the histopathological examination evaluated the presence of infiltrated inflammatory cells or the presence of inflammatory focus, defined as groups of at least 50 lymphocyte cells.

The counting of the focus in the total area of the glandular tissue for each examination was corrected to that corresponding to $4 \mathrm{~mm}^{2}$. The histological slices with the respective measured areas of glandular tissue were photographed.

The criteria, explained below, were applied for the classification of each case (Daniels \& Whitcher, 1994; Vitali et al., 2002):

1. Normal: preserved glandular parenchyma, with conserved acini and ducts.

2. Mild inflammatory process: presence of inflammatory cells in small quantity scattered in the periacinar conjunctive tissue.

3. Moderate inflammatory process: presence of inflammatory cells in moderate quantity scattered in the periacinar conjunctive tissue.

4. Severe inflammatory process: presence of inflammatory cells in great quantity, scattered in the periacinar conjunctive tissue and presence of dilated ducts.

5. One or more inflammatory focus in $4 \mathrm{~mm}^{2}$ of glandular tissue: presence of group of 50 or more inflammatory cells.

\section{RESULTS}

We observed the variation in the histological aspect of the glands, from normality up to the presence of inflammatory focus. The infiltrated inflammatory cells were present in the conjunctive, among the acini and ducts and in the glandular parenchyma as well (Fig. 1A-D).

In 11 cases $(27,5 \%)$ a normal histological aspect was observed. A mild inflammatory process was observed in 9 cases $(22,5 \%)$. A moderate inflammatory process was observed in only 1 case $(2,5 \%)$. Four cases $(10 \%)$ were classified as severe inflammatory process. In 15 cases $(37,5 \%)$, the presence of one or more inflammatory focus was observed (Table I).

Table I. Minor salivary glands classification in xerostomia individuals, with the presence of infiltrated inflammatory cells.

\begin{tabular}{lcl}
\hline \multicolumn{1}{c}{ Classification } & Number of cases (\%) \\
Normal & 11 & $(27,5)$ \\
Mild inflammatory process & 9 & $(22,5)$ \\
Moderate inflammatory process & 1 & $(2,5)$ \\
Severe inflammatory process & 4 & $(10,0)$ \\
One or more inflammatory focus & 15 & $(37,5)$ \\
in 4 mm $^{2}$ of glandular tissue & & \\
Total & $\mathbf{4 0}$ & $(\mathbf{1 0 0})$
\end{tabular}

\section{DISCUSSION}

The minor salivary glands histological aspect variability in xerostomia patients reflects the multiplicity of etiologies regarding this symptom. This variation includes the morphological normality, in which the structural lesion 

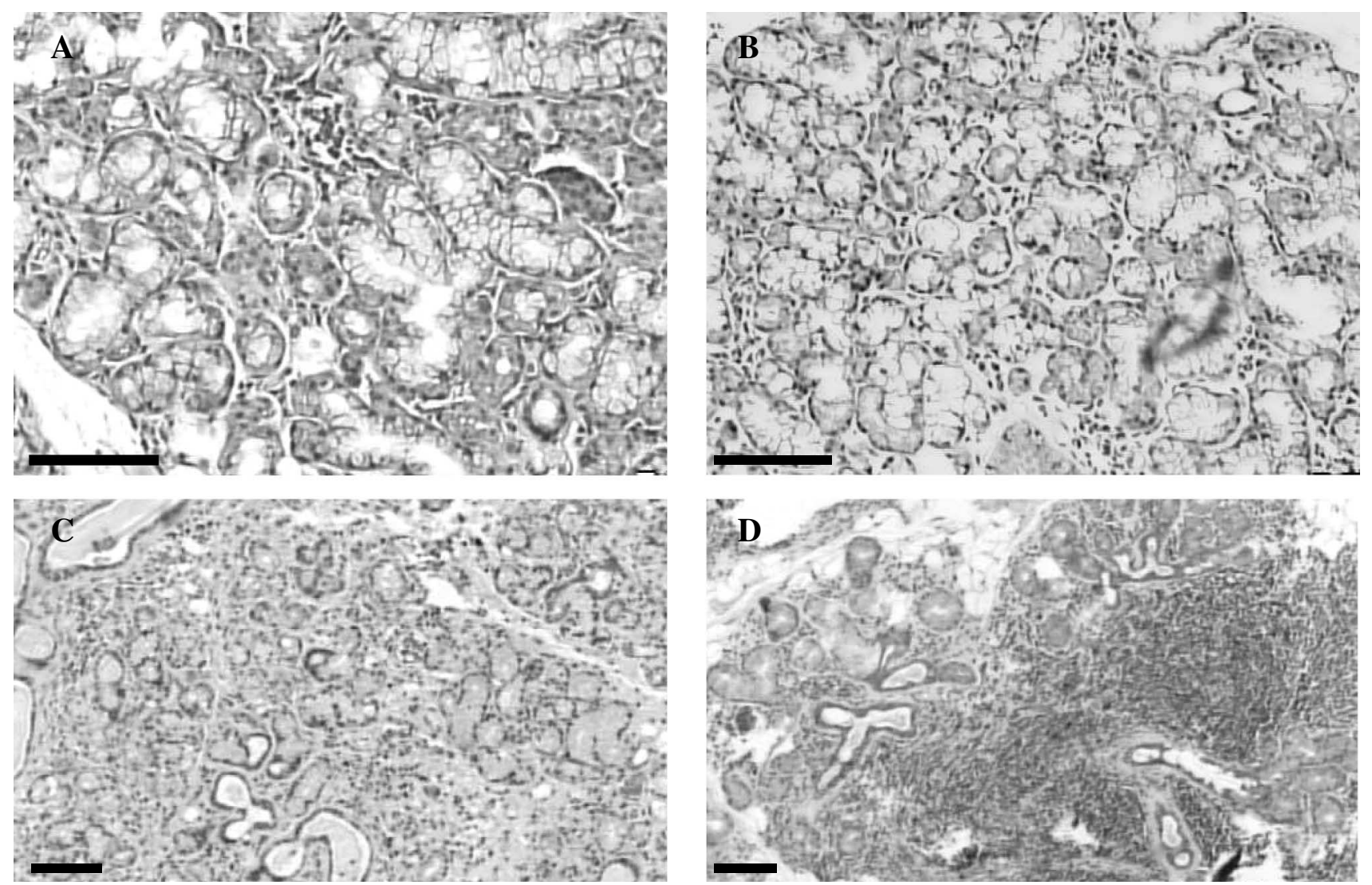

Fig. 1. Sections of HE stained minor salivary glands A: mild inflammatory process, showing the presence of inflammatory cells in small quantity scattered in the periacinar conjunctive tissue. B: moderate inflammatory process, showing the presence of inflammatory cells in moderate quantity scattered in the periacinar conjunctive tissue. C: severe inflammatory process, showing the presence of inflammatory cells in great quantity, scattered in the periacinar conjunctive tissue and dilated ducts. D: inflammatory foci replacing the glandular parenchyma. Bar $=100 \mu \mathrm{m}$.

in the glands is not evidenced, yet with functional implication, leading to several unspecified levels of inflammatory processes, up to the presence of inflammatory focus partially replacing the glandular parenchyma. During the analysis of the minor salivary gland, the presence of one or more inflammatory focus implied Sjögren's Syndrome (Chisholm \& Mason, 1968; Daniels, 1984; Daniels \& Whitcher, 1994; Fox et al., 1986; Greenspan et al., 1974; Vitali et al., 2002).

The classification of patients with Sjögren's Syndrome in scientific studies is not based in one test only, but in a set of criteria, keeping in mind that other diseases could take its course following a similar histological condition, such as hepatitis $\mathrm{C}$, sarcoidosis, and graft-versushost disease (Lindahl \& Hedfors, 1989; Vitali et al., 2002). There are several sets of criteria that have been applied in various research centers and, in all of them, the histological aspect of the minor salivary glands has been the most considered (Fox et al., 1986; Manthorpe, 2001; Vitali et al.,
2002). Such criterion has become mandatory for the American-European Consensus Group's classification (Vitali et al., 2002).

The method used for measuring the glandular area, by the Axiovision 3.1 ${ }^{\mathrm{TM}}$ program assistance for the delimitation of the glandular tissue area showed to be a good choice in substitution of the graticule, most commonly performed. (Chisholm \& Mason; Daniels, 1984; Daniels \& Whitcher, 1994; Greenspan et al., 1974).

There is variability in the histological aspect of the minor salivary glands for xerostomia patients, from morphological normality up to the presence of inflammatory focus. In 15 cases, the histological aspect suggested Sjögren's Syndrome, taken into consideration that the finding of at least one inflammatory focus in $4 \mathrm{~mm}^{2}$ of glandular tissue is a required criterion; however, it should not be considered the only one in order to classify the patient as having the Sjögren's Syndrome. 
There are a great number of researches taking place in order to improove the specificity of salivary gland biopsies to Sjögren's Syndrome by detection of IgA, IgG, insulinlike growth factor-I and other markers of inflamatory process by immunohistological techniques (Bodeutsch et al., 1992a, b; Markopoulos et al., 2000; Zandbelt et al., 2002), but there aren't until now, conclusive results. This way, the presence of focus, as well as positivity of anti-SSA and anti-SSB antibodies, remain the most specific criteria for classification. (Vitali et al., 2002)

\section{ACKNOWLEDGEMENTS}

The authors would like to thank to the CNPq Conselho Nacional de Desenvolvimento Científico e Tecnológico (National Council of Scientific and Technological Development) - Brazil - for the financial support for the realization of this work.

LIQUIDATO, B. M.; BARROS, M. D.; BUSSOLOTI FILHO, I.; PEREIRA, C. S. B. \& MACÉA, M. I. M. Morfología de las glándulas salivales menores en pacientes xerostomizados. Int. J. Morphol., 24(3):489-493, 2006.

RESUMEN: Las glándulas salivales menores son encontradas distribuidas a través de la mucosa oral, especialmente en los labios y en la mucosa del paladar blando. Varios factores pueden causar xerostomía, donde las características histológicas de las glándulas salivales son también consideradas como factores para definir la etiología. Así, las biopsias de las glándulas salivales menores representan una herramienta fundamental para alcanzar los criterios diagnósticos requeridos en la clasificación de pacientes con síndrome de Sjögren, ya que no representa riesgo para los pacientes. El objetivo de este estudio es determinar las características histológicas de las glándulas mencionadas, obtenidas de biopsias de pacientes con xerostomía y clasificar los aspectos histológicos de las glándulas en el síndrome de Sjögren. Estudiamos 40 láminas de pacientes con xerostomía, cuyas glándulas salivales menores fueron sometidas a biopsia en el Servicio de Estomatología de la Santa Casa de São Paulo, Brasil. Se observaron las variaciones de su aspecto histológico, desde la normalidad hasta la presencia de focos inflamatorios, los cambios del tejido conjuntivo entre los acinos y conductos, como también el parénquima. En 15 casos, el infltrado de células inflamatorias invadió el foco, es decir, grupos de al menos 50 células inflamatorias alrededor de acinos o conductos, lo cual es un aspecto característico del síndrome de Sjögren. Por lo tanto, el hallazgo de al menos un foco inflamatorio de $4 \mathrm{~mm}^{2}$ de tejido glandular, representa un buen criterio, aunque no es uno de los criterios a considerar cuando se trata de clasificar a los pacientes con el Síndrome de Sjögren.

PALABRAS CLAVE: Síndrome de Sjögren; Xerostomía; Glándulas salivales; Saliva; Diagnóstico.

\section{REFERENCES}

Bodeutsch, C.; de Wilde, P. C. M.; Kater, J. C.; van Houwelingen, J. C.; van de Hoogen, F. H. J; Kruize, A. A.; Hené, R. J.; van de Putte, L. B. A. \& Vooijs, G. P. Quantitative Immunohistologic criteria are superior to the lymphocytic focus score criterion for the diagnosis of Sjögren's syndrome. Arthritis Rheum., 35:1075-86, 1992a.

Bodeutsch, C.; de Wilde, P. C. M.; Kater, J. C.; Hené, R. J.; van de Hoogen, F. H. J; van de Putte, L. B. A. \& Vooijs, G.P. Labial salivary gland biopsy in Sjögren's syndrome. Neth. J. Med., 40:148-57, 1992.

Chisholm, D. M. \& Mason, K. Labial salivary gland biopsy in Sjögren disease. J. Clin. Pathol., 21:656-60, 1968.

Daniels, T. E. Labial salivary gland biopsy in Sjögren's syndrome. Assessment as a diagnostic criterion in 362 suspected cases. Arthritis Rheum., 27:147-56, 1984.

Daniels, T. E. \& Whitcher, J. P. Association of patterns of labial salivary gland inflammation with kerato- conjunctivitis sicca. Arthritis Rheum., 37:869-77, 1994.

Daniels, T. E. Evaluation, differential diagnosis, and treatment of xerostomia. J. Rheumatol. Suppl., 61:6-10, 2000 .

Fox, P. C. Differentiation of dry mouth etiology. Adv. Dent. Res., 10:13-6, 1996.

Fox, R. I.; Robinson, C. A.; Curd, J. G.; Kozin, F. \& Howell, F.V. Sjögren's Syndrome: Proposed criteria for classification. Arthritis Rheum., 29:577-85, 1986.

Greenspan, J. S.; Path, M. R. C.; Daniels, T. E.; Talal, N. \& Sylvester, M.D. The histopathology of Sjögren's syndrome in labial salivary gland biopsies. Oral Surg., 37:217-29, 1974.

Kierszembaum, A. L. Glândulas digestórias. In: Histologia e Biologia Celular: uma introdução à Patologia. Elsevier Editora, Rio de Janeiro, 2004. pp. 476-8. 
Lindahl, G.; Hedfors, E. Lymphocytic infiltrates and epithelial HLA- DR expression in lip salivary glands in connective disease patients lacking sicca: a prospective study. Br. J. Rheumatol., 28:293-8, 1989.

Markopoulos, A. K.; Poulopoulos, A. K.; Kayavis, I. \& Papanayotou, P. Immunohistochemical detection of insulin-like growth factor-I in the labial salivary glands of patients with Sjögren's syndrome. Oral Dis., 6:31-4, 2000.

Manthorpe, R.; Benoni, C.; Jacobsson, L.; Kirvata, Z.; Larsson, A.; Liedholm, R.; Nyhagen, C.; Tabery, H. \& Theander, E. Lower frequency of focal lip sialadenitis (focus score) in smoking patients. Can tobacco diminish the salivary gland involvement as judged by histological examination and anti-SSA/Ro and anti-SSB/La antibodies in Sjögren's syndrome? Ann. Rheum. Dis., 59:54-60, 2000.

Manthorpe, R. New criteria for diagnosing Sjögren's syndrome: a step forward? - Scand. J. Rheumatol. Suppl. 115:14-22, 2001.

Scully, C. The role of saliva in oral health problems. Practioner, 245:841-2, 845-8, 2001.

Vitali, C.; Bombardieri, S.; Moutsopoulos, H. M.; Balestrieri, G.; Bencivelli, W.; Bernstein, R. M.; Bjerrum, K. B.; Braga, S.; Coll, J.; De Vita, S.; Drosos, A. A.; Ehrenfeld, M.; Hatron, P. Y.; Hay, E. M.; Isenberg, D. A.; Janin, A.; Kalden, J. R.; Kater, L.; Konttinen, Y. T.; Maddison, P. J.; Maini, R. N.; Manthorpe, R.; Meyer, O.; Ostuni, P.; Pennec, Y.; Prause, J. U.; Richards, A.; Sauvezie, B.; Schiodt, M; Sciuto, M.; Scully, C.; Shoenfeld, Y.; Skopouli, F. N.; Smolen, J. S.; Snaith, M. L.; Tishler, M.; Todesco, S.; Valesini, G.; Venables, P. J. W.; Wattiaux, M. J. \& Youinou, P. Preliminary Criteria For Sjögren's Syndrome. Results of a prospective concentred action supported by the European Community. Arthritis Rheum., 36:340-7, 1993.

Vitali, C.; Bombardieri, S.; Jonsson, R. and The European Study Group On Classification Criteria For Sjögren's Syndrome. Classification criteria for Sjögren's syndrome: a revised version of the European criteria proposed by the American-European Consensus Group. Ann. Rheum. Dis., 61: 554-8, 2002.

Zandbelt, M. M.; Wentink, J. R. M.; de Wilde, P. C. M.; van Damme, P. A.; van de Putte, L. B. A. \& van de Hoogen, F. H. J. The synergistic value of focus score and $\operatorname{IgA} \%$ score of sublabial salivary gland biopsy for the accuracy of the diagnosis of Sjögren's syndrome: a ten year comparison. Rheumatology, 41:819: 23, 2002.

Correspondence to:

Dra. Bianca Maria Liquidato

Depto. de Morfologia da F. C. M. da Santa Casa de São Paulo

Rua Dr. Cesário Mota gr., 61. Santa Cecília

CEP 01221-020, São Paulo, SP,

BRASIL

Email:6mliqui@ig.com.6r

Received: 16-05-2006

Accepted: 17-07-2006 